\title{
OPENNESS AND GROWTH: A TIME- SERIES, CROSS-COUNTRY ANALYSIS FOR DEVELOPING COUNTRIES
}

Ann Harrison

Working Paper No. 5221

\author{
NATIONAL BUREAU OF ECONOMIC RESEARCH \\ 1050 Massachusetts Avenue \\ Cambridge, MA 02138 \\ August 1995
}

This paper was prepared as a background paper for World Development Report 1991. I would like to thank members of the World Development Report 1991, Bill Easterly, Mike Finger, Frank Lichtenberg, John Nash, Lant Pritchett, David Richardson, David Wheeler and especially two anonymous referees for helpful comments and suggestions. The databases in this paper may be obtained from the World Development Report division at the World Bank (202-473-1393) and Vikram Nehru (also at the World Bank) at 202-473-3887. This paper is part of NBER's research program in International Trade and Investment. Any opinions expressed are those of the author and not those of the National Bureau of Economic Research.

(C) 1995 by Ann Harrison. All rights reserved. Short sections of text, not to exceed two paragraphs, may be quoted without explicit permission provided that full credit, including $\odot$ notice, is given to the source. 


\title{
OPENNESS AND GROWTH: A TIME- SERIES, CROSS-COUNTRY ANALYSIS FOR DEVELOPING COUNTRIES
}

\begin{abstract}
This paper draws together a variety of openness measures to test the association between openness and growth. Although the correlation across different types of openness is not always strong, there is generally a positive association between growth and different measures of openness. The strength of the association depends on whether the specification uses cross-section or panel data (which combines cross-section and time series). For industrializing countries, which have exhibited significant fluctuations in trade regimes over time, long run averages may not serve as very meaningful indicators of policy.
\end{abstract}

\author{
Ann Harrison \\ Graduate School of Business \\ Columbia University \\ 615 Uris Hall \\ New York, NY 10027 \\ and NBER
}


The new interest in the determinants of economic development has reignited the debate on openness and growth. In neoclassical growth models developed by Solow (1956) and others, technological change is exogenous--unaffected by a country's openness to world trade. Yet the "new" growth theories suggest that trade policy affects long run growth through its impact on technological change. ${ }^{1}$ In these models, openness to trade provides access to imported inputs, which embody new technology; increases the effective size of the market facing producers. which raises the returns to innovation; and affects a country's specialization in research-intensive production.

New growth theories. however, do not predict that trade will unambiguously raise economic growth. Increased competition (as Schumpeter argued) could discourage innovation by lowering expected profits. Grossman and Helpman (1991) point out that intervention in trade could raise long run growth if protection encourages investment in research-intensive sectors for countries with an international advantage in these kinds of goods. Since the theoretical literature does not provide a clear answer, empirical work is needed to help resolve the debate.

Despite the already voluminous empirical efforts in this area, it is easy to be skeptical of past results for a number of reasons. First, different studies have used a dizzying array of "openness" measures, methodologies, and sample countries, leading to results which may differ for any number of reasons. Most research has examined the relationship between economic growth and trade volumes, not policies--this is partly because measuring "policy" poses difficult questions. Second, it is sometimes difficult to know how to interpret the observed correlation between trade policies and growth (see Levine and Renelt (1992)).

${ }^{1}$ See, for example, Grossman and Helpman (1991) or Romer (1991). 
Policies that are not directly concerned with trade (macroeconomic policy, educational policies) may have caused both superior export performance and high GDP growth.

Third, most of the literature (including Barro (1991) and others) uses cross-sectional averages or starting values for time-series data. Barro (1991), for example. examines the impact of price distortions in 1960 on post-1960 GDP growth. Applying such an approach to developing countries has two shortcomings. First, the use of cross-section data makes it impossible to control for unobserved country-specific differences, possibly biasing the results. Second, long run averages or initial values for trade policy variables--particularly in developing countries--ignore the important changes which have occurred over time tor the same country. In this paper, we use a panel dataset--which pools cross-section and time series data for developing countries--as an alternative approach.

Section I reviews the empirical literature on openness and technological change. Section II discusses the dataset for this paper and the empirical specification. while Section III presents the main results. We examine the robustness of the results in Section IV, and extend the analysis to examine the relationship between openness and investment. Section $V$ presents the results of causality tests, while Section VI concludes and makes suggestions for future research.

I. An overview of the literature on openness and economic growth

The concept of openness, applied to trade policy, could be synonymous with the idea of neutrality. Neutrality means that incentives are neutral between saving a unit of foreign 
exchange through import substitution and earning a unit of foreign exchange through exports. Clearly, a highly export oriented economy may not be neutral in this sense, particularly if it shifts incentives in favor of export production through instruments such as export subsidies. It is also possible for a regime to be neutral on average, and yet intervene in specific sectors. A good measure of trade policy would capture differences between neutral, inward oriented, and export-promoting regimes.

Price comparisons between goods sold in domestic and international markets could provide an ideal measure of the impact of trade policy, particularly in the absense of domestic policy distortions. Direct price comparisons would incorporate the impact of the various policies that affect domestic prices: tariffs, quotas, different exchange rates for imports and exports, and subsidies. Since information on relative prices is often not available, however, many other proxies are often used instead.

The simplest measures of trade orientation are based on actual trade flows, such as imports plus exports as a share of GDP or the growth rates of imports and exports. Most of these measures show a positive association with GDP growth, even after controlling for other factors such as capital or labor (Section I, Table 1). One problem with this approach, however, is that trade flows are at best an imperfect proxy for trade policy. Other factors, such as country size or foreign capital inflows, also affect trade: large countries, for example, generally have smaller trade shares. One improvement over this approach is to use the deviation of actual from predicted trade flows (as in Syrquin and Chenery (1989)), based on variables such as country size. Another approach, introduced by Leamer (1988), uses a theoretical model to predict the pattern and volume of trade in the absense of protection. 
Leamer then measures "openness" as a function of the extent to which actual trade deviates from the pattern of trade predicted by the model. Edwards (1992) has used Leamer's measure to show a positive and statistically significant impact of openness on growth. ${ }^{2}$

Direct measures of trade barriers include administrative data, such as average tariff rates or coverage ratios for nontariff barriers. Problems typically arise, however, in attempting to aggregate these data into an overall index. Coverage ratios for nontariff barriers cause the greatest difficulty. These measures are typically calculated in one of two different ways. The first approach is to calculate the coverage ratio as the percentage of imports covered by trade barriers. which means that effective barriers that exclude most imports receive little weight. The second approach is to compute the percentage of product categories that are subject to import licenses. This approach, however, gives no information on the extent to which quotas are binding, nor can we measure the impact of relaxing quotas on trade flows. The coverage ratio only suggests that barriers to trade exist, but cannot measure their effect. ${ }^{3}$

Research on trade and growth using both price-based or administrative measures has increased in the last several years. Studies based on these types of measures have generally

${ }^{2}$ Although this approach is quite promising, Pritchett (1991) shows that Leamer's openness measure is inversely related to other measures of openness, such as import penetration, quotas, and tariffs. In other words, if Leamer's measure suggests that a country is relatively open, this country is also likely to have high tariffs and quotas, or low import penetration. In his paper, Leamer (1988) concludes that "in the absence of direct measures of barriers, it will be impossible to determine the degree of openness for most countries with much subjective confidence."

${ }^{3}$ For a discussion of the relationship between these administrative measures and other indicators of openness, see Pritchett (1990). 
found a positive relationship between trade and growth (Section II in Table 1). Yet these more recent efforts to identify the impact of openness on economic growth have relied on the use of cross-sectional averages of time-series data. Applying such an approach to developing countries makes it impossible to control for unobserved country-specific differences and also ignores the important changes which have occurred over time for the same country.

Micro studies (Section III, Table 1) have generally shown a positive association between increased exports and productivity growth (for an overview of the literature on trade and productivity, see the survey by Pack (1989)). However, the relationship between imports and productivity growth is often negative. This asymmetry is likely to be due to two factors, both related to estimation problems arising from simultaneity bias. First, countries tend to export goods in which they have a comparative advantage and to import goods in which they do not. Past empirical work--which generally ignores any problems due to simultaneity--has been unable to distinguish between the expected positive effect of imports on productivity growth in the long run and the fact that imports are drawn to low productivity sectors where a country does not have an international advantage. Second, the observed relationships could also be explained by the well-known pro-cyclical nature of productivity growth: productivity growth tends to be higher when output is growing, and falls during recessions or low-growth periods. Consequently, if greater import penetration is accompanied by a contraction of domestic industry, it is not surprising that productivity growth also falls. ${ }^{4}$

4 One paper which has been able to convincingly address this simultaneity problem is Kaufman (1991). Using micro-level data on the rate of return to World Bank investment projects, Kaufman finds that a range of policies--including trade and exchange rate policies-- 
One difficulty in measuring the impact of trade policies on growth is that trade policy itself may be a function of other variables, including growth. Studies that have tried to identify the causal relationship between GDP growth and growth in exports or imports have had mixed results (Section IV, Table 1).

This brief review of the literature on openness and economic growth reveals two important considerations. First, despite the voluminous literature on this topic, the debate is by no means resolved. Many studies do reveal a positive relationship between various measures of openness and growth. But nagging problems remain. Methodological shortcomings make it difficult to link performance outcomes with policies per se; causality tests and micro-level analyses yield mixed results.

Second, it should be evident that no independent measure of so-called "openness" is free of methodological problems. Even the most recent use of direct price comparisons, facilitated by the work of Summers and Heston (1988), is plagued by small sample size--the data have not been collected for the same set of benchmark countries over many years. This may be one factor which has led to an emphasis on the use of cross-section estimation. In addition, international price comparisons cannot disentangle the impact of domestic market imperfections (such as oligopolistic marketing channels for imported goods) from trade policy interventions.

Consequently, the approach adopted in this paper is to gather as many different measures of openness as are available for a cross-section of developing countries over time,

significantly affect the rate of return to projects. A more open policy environment can double the rate of return to investment, even after controlling for general economic trends, such as GDP growth. 
and test whether these measures generally yield the same results. Unfortunately, we are forced to exclude a number of openness measures which are not available over time, such as the indices computed by Leamer (1988), and the comprehensive data on tariffs and non-tariff barriers gathered by UNCTAD for a cross-section of developing countries in $1987 .{ }^{5}$

II. Data and correlations between openness variables.

Data Sources The empirical specification in this paper is derived from a general production function, with output (GDP) as a function of capital stock, years of primary and secondary education, population, labor force, arable land, and technological change. The production function is specified for country $i$ at time $t$ :

$Y_{i t}=A_{i t} G\left(K_{\text {STOCK }}\right.$, PRIMSTOCK $_{i t}$, SECSTOCK $_{i t}$, LABOR $_{\mathrm{it}}$, LAND $\left._{\mathrm{i}}\right)$.

Totally differentiating (1), dividing through by $\mathrm{Y}$, and rearranging terms yields:

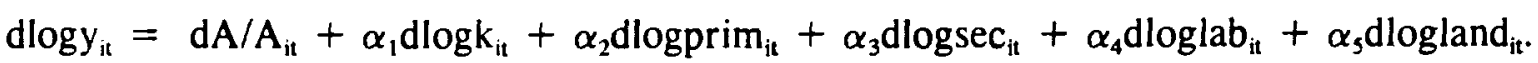

(2)

s See Pritchett (1991) for further details regarding the UNCTAD data. Pritchett (1991) uses cross-section data to compare a number of different openness measures, including the UNCTAD and Leamer measures. Although we considered using the UNCTAD data to estimate the impact of 1987 tariff and non-tariff barriers on consequent growth, not enough post-1987 data was available to do this exercise. 
Lower case variables dlogy, dlogk, dlogprim, dlogsec, dloglab and dlogland have been transformed into differences of logs of the original variables. Openness measures (or other policy variables) in the production function affect output through their impact on technological change. The term $\mathrm{dA} / \mathrm{A}$ can be rewritten as the sum of three effects: (1) a country-specific effect $f_{i}$ which does not change over time (2) a disturbance term $e_{i t}$ and (3) a third term, which is a function of trade policy in country $i$ at time $t$. The disturbance term e reflects unobserved shocks which nevertheless affect output, which are assumed to be uncorrelated over time. This could include shocks such as weather conditions, changes in the availability of (unobserved) inputs, or other effects. The assumption of lack of serial correlation was tested on a country-by-country basis by applying a Durban-Watson test to the residuals. This yields an estimating equation:

$$
\begin{gathered}
\mathrm{dlog}_{\mathrm{it}}=\mathrm{dA} / \mathrm{A}_{\mathrm{it}}+\alpha_{1} \mathrm{dlogk}_{\mathrm{it}}+\alpha_{2} \text { dlogprim }_{\mathrm{it}}+\alpha_{3} \text { dlogsec }_{\mathrm{it}}+\alpha_{4} \text { dloglab }_{\mathrm{it}}+\alpha_{5} \mathrm{dlog}_{\operatorname{land}}+ \\
\alpha_{6} \text { OPENNESS }_{\mathrm{it}}+\mathrm{f}_{\mathrm{i}}+\mathrm{e}_{\mathrm{it}}
\end{gathered}
$$

Inclusion of openness measures (or other policy variables) in the production function is consequently a test of their impact on technological change--growth in output after controlling for increases in resource use. The general specification outlined above makes no 
restrictions on returns to scale or the degree of competition. ${ }^{6}$ As a result, the sum of the input coefficients need not add up to unity.

GDP growth is calculated as log differences using national accounts data in 1980 dollars, collected by the World Bank. Physical and human capital stocks were calculated by Nehru and Dhareshwar (1993) and Nehru, Swanson, and Dubey (1993). Nehru et al. compute capital stock and years of education from annual capital investment and educational enrollment data, using the perpetual inventory method for investment and a similar approach for educational stocks.

All values are transformed into differences of log values, with the exception of the openness measures, where both levels and changes in openness are alternatively included as independent variables. We also experimented with defining human capital in both levels and differences. In a neoclassical growth model, it is easy to show that GDP growth can be derived as a function of changes in the stock of education (see, for example, Mankiw, Romer and Weil (1992)). However, it is also possible to model GDP growth as a function of the level of human capital (see, for example, Benhabib and Spiegel (1992)). Since our model is essentially a neoclassical Solow model, modified to allow technological change to vary with trade policies, GDP growth is initially specified as a function of changes in human capital. Later in the paper, however, GDP growth is also modelled as a function of the level of human capital stock.

${ }^{6}$ See Harrison (1993) for an exposition on the extent to which assumptions of constant returns to scale and perfect competition lead to biased estimates of traditional productivity residuals. 
Seven different proxies for trade and exchange rate policies were collected from different sources to test the statistical relationship between openness and growth. The first measure (TR I), an annual index of trade liberalization for 1960-84, was derived using country-specific information on exchange rate and commercial policies (Source:

Papageorgiou, Michaely, and Choksi, 1990). A second index of trade liberalization for 1978-88 (TR II) was calculated using country sources on tariffs and nontariff barriers (source: Thomas, Halevi, and Stanton, 1991). The third measure is the black market premium (BLACK), which is defined as the deviation of the black market rate from the official exchange rate (source: International Currency Analysis, Inc., various years). The fourth measure (TR Share) is simply the share of trade in GDP. defined as the ratio of exports plus imports to GDP (source: World Bank). The fifth measure calculates movements toward international prices (MTIP). The MTIP index was derived from the relative price of a country's tradables, which was computed using current and constant national accounts price indexes (for more details, see Bhalla and Lau (1992)). This variable uses as a benchmarket the relative price of consumption goods for 1980 from Summers and Heston (1988). It is then transformed to measure the movement toward unity. The sixth measure (DOLLAR), is a modified version of the price distortion index used in Dollar (1991). The relative price of consumption goods from Summers-Heston is "purged" of its non-traded component by taking the residual from a regression of this index on urbanization, land, and population. Countries with high values for the DOLLAR index have high relative prices for consumption goods, which suggests a more distortionary trade regime. The seventh indicator (INDIRECT) measures the indirect bias against agriculture from industrial sector protection and 
overvaluation of the exchange rate (source: Schiff, and Valdes (1991)). A higher value of INDIRECT suggests lower industrial protection and overvaluation of the exchange rate. Annual observations were available for time periods which ranged from 1960-87 for trade shares to $1978-88$ for the Thomas et al. trade liberalization index. The number of countries available for each index varies, ranging from 51 to 17 . More details on country coverage by trade indicator are provided in Appendix 1.

Data Quality Issues Issues of data quality and comparability are likely to be particularly problematic for cross-country, time series data.' Countries often use different definitions and data collection techniques. This problem is likely to be severe (see Behrman and Rosenzweig (1994)) for educational investments and labor force data. In some cases, data are not gathered annually and interpolations are used to fill in the missing gaps. Data are also likely to be systematically gathered for some countries or regions and not for others, yielding sample selection problems.

Although the country coverage for the seven different openness indicators is not complete (see Appendix 1), there is significant variation in coverage across the different measures. In fact, there is so little overlap in country coverage across the different measures that it would have been impossible to include multiple indicators of openness in the same regression. Consequently, the different results presented in the paper are the outcome of using very different policy measures and varying the country coverage at the same time.

${ }^{7}$ For a more complete discussion of data quality issues, see Ahmad (1994), Behrman and Rosenzweig (1994), Heston (1994), and Srinivasan (1994). 
Data on arable land. capital stock, GDP growth, and openness measures are all reported on an annual basis. The labor force and educational stock variables (which are in turn calculated using enrollment data) are based on surveys and censuses which are generally not repeated on an annual basis; interpolation for these two measures is inevitable. The problems associated with creating a cross-section, time series panel for labor force and educational stocks suggests that the coefficients on these variables should be treated with caution.

A variety of specifications were used to test the robustness of the results.

Estimation was redone using several different definitions and measures of human capital, including primary and secondary enrollment rates, literacy rates, and the educational stock variable reported in Barro and Lee (1993). None of the alternative specifications had any impact on the observed empirical relationship between openness and GDP growth, and consequently are not reported in the paper. The results presented in the paper were also reestimated using another series for physical capital and human capital stocks prepared for the World Development Report 1991.

The problem of data comparability across countries is addressed by focusing on the time series, not the cross-country results. In all but the cross-section estimation, country dummy variables are included as independent variables. Focusing on the determinants of GDP growth within an individual country over time minimizes the importance of differences across countries at any point in time. To the extent that differences in coverage or data definitions persist over time, this may help to minimize the bias which arises from differences in data definitions or coverage across countries. This approach does not eliminate 
problems of comparability, however. As pointed out by Behrman and Rosenzweig (1994), however. data definitions and coverage are likely to change even within the same country over time.

Correlation across openness measures Tables 2 and 3 examine the rank correlation between these seven different measures of openness. Table 2, which examines the rank correlation between openness measures in levels, excludes the measure for movement towards international prices, which is an estimate of changes in policy. The results suggest that there is generally a statistically significant (and positive) correlation between the two measures of trade reform, minimal disprotection of agriculture, and trade shares. This positive relationship exists for both levels of openness as well as changes, for a pure cross section as well as for a panel. However. the majority of the rank correlations using the pure cross section (averages of the time series for each country) are not statistically significant. In many cases, the value of the rank correlation is unchanged across the annual and cross-section samples, but the significance is simply much lower for the cross-section data.

As expected, there is also a negative relationship between those four measures and the extent of a black market premium. The rank correlations in Tables 2 and 3 confirm that inappropriate levels of the official exchange rate, proxied by the black market premium, are generally inversely associated with "open" trade policies. Of course, these correlations do not indicate the direction of causation between exchange rate and trade policies; they only indicate that the two are significantly related. 
The two remaining measures employed in the analysis, both measures of price distortions, do not show a consistent or generally significant relationship with the other measures (see Tables 2 and 3). Although the lack of an association between these measures and the others is surprising, it says nothing about the extent to which one measure is necessarily preferable to others. The lack of a perfect (or even appropriately signed) correlation between all these measures is likely to indicate that they are not capturing the same aspects of "openness": the black market premium, for example, is a direct measure of the extent to which inappropriate exchange rate policies may trigger (or be a consequence of) protection.

III. Basic Results

Table 4 presents the first set of regression results. Period averages were computed over time for each country to create a pure cross-section estimation across countries. The size of each sample depends on the country coverage of each openness measure (see Appendix 1), as well as the availability of educational and capital stocks.

For the pure cross-country regressions reported in Table 4, GDP per capita in 1960 is also included as an independent variable. Barro (1990), Edwards (1992), Levine and Renelt (1992), Mankiw, Romer and Weil (1992), and others generally include initial per capita GDP in their cross-country growth regressions. The coefficient on initial GDP per capita has been interpreted as a test of the convergence hypothesis; neoclassical growth models predict that per capita growth rates tend to be inversely related to initial GDP per 
capita. As pointed out by Lichtenberg (1994), however, this is actually a test of mean reversion. which is a necessary but not a sufficient condition for convergence. Another interpretation, suggested by Edwards (1992), is that countries with a lower initial per capita income have greater opportunities to 'catch up' with more advanced nations.

The results in Table 4 suggest that after controlling for other inputs, measures of openness calculated as averages over several decades are generally not significant in explaining growth. The only variable which is statistically significant across the seven measures is the black market premium, which has the correct sign. A higher black market premium is negatively associated with growth. Among the other factors, the most important variables are the growth of labor force and capital stock: on average a one percent increase in capital accounts for an increase in the rate of GDP growth of between .4 and .6 percent. Initial GDP per capita is insignificant and close to zero in every case; this suggests that our developing country sample did not exhibit any convergence in growth rates after accounting for other factors. The coefficients on arable land and human capital are also insignificant in every case. One possible reason for the insignificant impact of arable land is that it changes very slowly over time. As discussed earlier in the paper, there are significant data problems associated with the human capital measure. ${ }^{8}$

Although a large share of earlier research has focused on period averages to identify the determinants of long run growth, using period averages is likely to hide significant variations in individual country performance. Most developing countries have experienced

8 Only one specification, which used the stock of education at the beginning of the sample period, showed a positive and statistically significant association between average years of education and the rate of GDP growth. 
large swings in commercial and exchange rate policies over the last thirty years, which could render any proxies for openness essentially meaningless. Due to the large variation in country policies since the 1950s, beginning of period values could also have little explanatory power. Consequently, the regressions were redone using annual data for the same variables. To control for unobserved country-specific differences in growth rates, we included dummy variables for each country--the so-called fixed effects model. Since we include country dummy variables, we cannot include initial per capita GDP (which also varies across countries but not over time). ${ }^{9}$ The country effects control for any persistent differences across countries. such as initial conditions, higher level of technical know-how, cultural differences, or freer access to knowledge. The results are given in Table 5.

The cross-country time series panel results in Table 5 show a stronger relationship between the seven openness measures and growth. Three openness measures are significant at the 5 percent level, and another is significant at the 10 percent level. All the measures except trade shares have the expected sign--movements toward openness positively affect growth; greater distortions (as measured by the black market premium and modified Dollar (1991) measure) negatively affect growth. The F-tests reject the null hypothesis that country effects are not important in columns (2), (3) and (5). In these cases, the country dummies are jointly significant--suggesting the presence of country-specific differences that persist over time.

${ }^{9}$ As pointed out by one referee, it would have been possible to re-introduce initial per capita GDP with fixed effects if initial GDP refers to the initial GDP for each sub-period-such as the first year in each of the five-year averages used later in the paper. However, since initial GDP was insignificant in the cross-section, it did not seem worthwhile to pursue additional specifications with some modifications to this variable. 
One major problem with using annual data to identify the determinants of long run growth is that short term or cyclical fluctuations could affect the observed relationship between policy variables and growth. Many countries faced with large, negative external shocks sometimes treat those shocks as temporary, allowing a real appreciation of the exchange rate and imposing import restrictions concurrently with low or negative growth. Quah and Rauch (1990), who use trade shares as a proxy for openness, find that most of the observed positive relationship between openness and growth is due to short-run cyclical fluctuations. Consequently, we also compute five-year averages for 1960 through 1987. These results are given in Table 6.

The five-year averages reveal a statistically significant (at the 5 percent level) and positive relationship between openness and growth for two of the measures. Another measure, the modified Dollar index, is significant at the 10 percent level with the expected sign. The three statistically significant measures (TR II, Black and Dollar) are the same measures which were statistically significant in the annual data.

Table 7 presents the period averages, annual data, and six-year averages when changes in openness, instead of levels, are included as independent right-hand side variables. Static trade models do suggest that movements towards openness can temporarily increase the rate of growth due to short-run gains from the reallocation of resources, which would imply a positive relationship between changes in openness and GDP growth. Recent efforts to model the impact of openness in a dynamic framework predict that both levels and changes in openness can have a long-run impact on growth. 
The results in Table 7 show that movement towards a more open trade regime, with only one exception, is associated with higher GDP growth, after accounting for other inputs. The coefficient on openness is statistically significant at the 5 percent level for 4 out of 7 measures using annual data, for 2 out of 7 measures if we use 5 year averages, and for 2 out of 7 measures using period averages. The coefficient on openness is the wrong sign only for the measure TR II in the period averages.

Table 8 summarizes the relationship between openness and growth presented in Tables 4 through 7 . Using five-year averages or annual data, the different specifications show a positive, often significant association between the various measures of openness and productivity growth. However, using cross-sectional data only reveals a significant relationship between openness and growth for two of the seven indicators, one of which has an incorrect sign. ${ }^{10}$

IV. Alternative Specifications and Sensitivity Results

Interaction between openness and human capital The results appears to suggest a persistent relationship between higher growth of disembodied technical change and levels (or changes)

${ }^{10}$ I also plotted the partial correlations between all seven measures of openness and productivity growth, using five-year averages. The results are reported in an earlier version of this paper, which is available as World Bank Working Paper \#451 (November, 1991). The scatter plots reveal an important stylized fact: although the partial correlations are generally statistically significant, explanatory power of these seven measures varies. The Rsquare on the partial correlations ranged from .03 to .30 , indicating that although trade policy is important, much variation in growth rates is still unexplained, even after accounting for changes in education, labor, land, and capital stock. 
in openness. However, some have argued that openness is primarily associated with growth in countries with enough human capital to effectively absorb new information (see Edwards (1992), Levin and Raut (1992), and Bhalla and Lau (1992)). This suggests including the interaction between openness and the level of human capital as an independent variable. In such a alternative specification, openness is associated with both higher productivity growth as well as higher returns to human capital. An alternative interpretation is that the benefits from openness are higher for a more educated population.

Table 9 presents the coefficient on the interaction of human capital and trade policy. The level of human capital was also included a separate regressor, but since the coefficient on all specifications was statistically insignificant, it is not reported here. The coefficient on the interaction term is statistically significant for three of the seven measures. However, the sign of the coefficient is not consistent across openness measures. Openness raises the return to human capital only if we focus on the black market premium. If, however, we measure openness using TR I or TR Share, we get very mixed results. Greater openness is associated with a lower return to primary schooling but a higher return to secondary schooling. This suggests that the interaction between openness and returns to human capital is not a robust relationship in this particular dataset.

Sensitivity Results Past efforts to isolate the impact of openness on growth have generally failed to control for other factors. ${ }^{11}$ Prudent macroeconomic policies--which often go hand in hand with more open trade and exchange rate policies--may lead to higher productivity

\footnotetext{
1 Two exceptions are Edwards (1992) and Levine and Renelt (1991).
} 
growth. If so, then excluding these variables from the analysis may lead to mistakenly identifying the gains from trade instead of the real cause--macroeconomic stability. ${ }^{12}$ For example, Levine and Renelt (1992) found that the positive association between trade shares and GDP growth disappeared in a cross-section of countries when they included government expenditures in the regression.

In their paper. Levine and Renelt (1992) apply a variant of the extreme bounds analysis (EBA) developed by Leamer (1983) to test the sensitivity of their cross-country regression results. From a pool of seven widely used variables in cross-country analysis, they choose a subset of up to three variables and examine the robustness of their basic results to including additional variables. They rotate the pool of variables, using every possible combination of 3 variables from the seven chosen. Unfortunately, the variables they use are not available over time for the same set of countries used in our analysis. Consequently, we were only able to include three variables in our sensitivity tests: terms of trade shocks, government consumption, and the rate of inflation. In the spirit of Easterly, Kremer, Pritchett, and Summers (1993), terms of trade shocks are calculated as the change in export

${ }^{12}$ In an earlier version of this paper, we also examined the possibility that large countries benefit less from more open trade policies than smaller countries. If one of the primary gains from more open trade regimes is through greater competition, then it could be possible for domestic competition in large countries to substitute for the effects of trade. To test this hypothesis, two different measures of country size (level of the population and GDP) were included as independent variables and interacted with our 7 openness measures. If large countries benefit less from more open policies than small countries, then the coefficient on the interaction of trade policy and size should be opposite in sign to the coefficient on openness, mitigating its effect. The results did show a mitigating effect, but none of the coefficients were statistically significant. 
prices, weighted by the share of exports in GDP, minus the change in import prices, weighted by the share of imports in GDP.

The results are presented in Table 10. The analysis only includes openness variables which were statistically significant at the five percent level (in either levels or changes) in Tables 4 through 7 . When the three additional macro variables are included, the statistical significance of the openness measures disappears in half the cases. The measures which are robust to inclusion of additional variables are the black market premium (in the cross-section, annual data, and five year averages), the Halevi measure (TR II), and the movement towards international prices (MTIP). The variables which are not robust include TR I, DOLLAR, and trade shares.

Interpreting these results is somewhat problematic. On the one hand, it appears that half the measures used to proxy for openness are not robust to the inclusion of macroeconomic variables. This may suggest that openness variables do in fact act as a proxy for other movements in the economy, invalidating the positive relationship between openness and GDP growth. On the other hand, the possibility of strong multicollinearity between the right-hand side variables means that disentangling the impact of various macro and trade measures may be very difficult. Levine and Renelt (1992) find that almost all measures used in their extensive assessment of the determinants of long run GDP growth are fragile. In other words, there generally exists a set of additional variables which eliminate the statistical significance of any one explanatory variable in a cross-country growth regression. Viewed in this light, our results are encouraging; half our measures do appear to be robust. 
Openness and the share of investment in GDP One of the few robust findings in Levine and Renelt (1992) is a positive correlation between the share of investment in GDP and the average share of trade in GDP. Levine and Renelt use this result to suggest that the linkages between trade and growth may occur through investment, instead of through improved resource allocation. Since growth in capital stock is significantly correlated with GDP growth, trade policies may be important only insofar as they provide greater access to investment goods.

In Table 11, we reproduce the sensitivity analysis presented in Table 10, but replace GDP growth with the investment share of GDP as our dependent variable. The only independent variables included in the specification are government spending, inflation, terms of trade, and the openness measure. The results confirm a robust and positive relationship between trade shares and the investment share in GDP. However, there is no consistent or robust relationship between investment shares in GDP and any of the other openness measures. For example, more distorted policies (as measured by DOLLAR or BLACK) are associated with a higher investment share in GDP. Other measures (such as INDIRECT) show both a positive and negative association with investment shares, depending on whether we use cross-section averages or annual data. One possibility is that different openness measures capture different aspects of the openness-GDP growth relationship. While the relationship between trade shares and GDP growth may operate via investment, other openness measures appear to be directly associated with a more efficient allocation of resources or a higher rate of technical progress. 
V. Causality Issues

One issue which has been relatively neglected in the current research on crosscountry growth is the problem of causality. Does openness cause growth? Or is it the other way around? Historical evidence seems to suggest that causality runs in both directions. Some countries. including Korea and Singapore, experienced an import substitution phase in conjunction with respectable rates of GDP growth. It is possible that such policies helped spur exports, which in turn generated long run growth. In the United States, protectionist tariffs which averaged 40 percent were not dismantled until the middle of the 1930 s. Calls for protectionism re-emerged after growth declined and imports rose, beginning with the steel and textile industries in the 1960s and culminating in the protectionism of the $1990 \mathrm{~s}$.

One way to explore this issue is to apply causality tests using vector autoregressions (VARs) to investigate the direction of causation between openness and growth. The limitations of such tests are well known: simply because a variable $\mathrm{x}$ precedes a variable $\mathrm{y}$ in a time series, or leads to improved predictions for $y$, cannot be taken as proof that $x$ causes $y$. Yet in the context of cross-country growth regressions, where it appears almost impossible to find an instrument for openness which is not correlated with growth, applying VARs appears to be a first step towards analyzing the problem of causality.

To test for Granger causality between openness and growth, an equation was estimated of the following form:

$d y_{i t}=$ 


$$
\alpha_{0}+\alpha_{1} \mathrm{dy}_{\mathrm{i}, \mathrm{t}-1}+\alpha_{2} \mathrm{dy}_{\mathrm{i}, t-2}+\alpha_{3} \mathrm{dy}_{\mathrm{i},-3}+\mathrm{B}_{1} \mathrm{dx}_{\mathrm{i}, t-1}+\mathrm{B}_{2} \mathrm{dx}_{\mathrm{i}, t-2}+\mathrm{B}_{3} \mathrm{dx}_{\mathrm{i}, t-3}+\mathrm{f}_{\mathrm{i}}+\mathrm{u}_{\mathrm{t}}
$$

The variable $\mathrm{x}$ is said to Granger "cause" $\mathrm{y}$ if we reject a joint $\mathrm{F}$ test of the hypothesis that the B's are equal to zero. If the dependent variable is replaced by $\mathrm{dx}$, we can then test whether $y$ also Granger "causes" x. Equation (4) was estimated for GDP growth, the openness measures listed in Table 12, and all the other right-hand side variables included in the earlier tables (capital stock, education, land, labor force.) Only the causality tests for openness and growth are reported in Table 12. Given the short time series for the five year averages. only the annual data were used. Three lags of each variable were included on the right-hand side.

One problem which arises in estimating (4) is that the OLS estimates are biased in the presence of country fixed effects and lagged dependent variables. However, Nickell (1981) has shown that the bias is inversely related to the number of years in the sample. Since the time series spans twenty-seven years, the bias in the estimates is likely to be small. Consequently, even in those cases where fixed effects were found to be statistically significant (equations using BLACK, TR II, and Trade Share), equation (4) was estimated using ordinary least squares.

The results in Table 12 suggest that causality between openness and growth runs in both directions. For trade shares, the results suggests that causality runs in both directions: lagged values of GDP growth are significant in explaining openness, while lagged openness is significant in explaining GDP growth. For the black market premium, however, causality runs only from openness to growth. 
These results are consistent with earlier results (see Section IV of Table 1) which focused only on trade shares as an openness measure and performed causality tests on a smaller sample of countries. The results in Table 12 suggest that the debate on the direction of causality between openness and growth is by no means resolved. Periods of high GDP growth are likely to provide an important inpetus for more open markets, while declining growth rates are likely to fuel protectionism. One cannot assume, as some empirical growth exercises are likely to do, that the causality between country policies and GDP growth only runs in one direction.

VI. Conclusion and Directions for Further Research

This paper measures the impact of a wide range of openness measures on economic growth. The results suggest that the choice of time period for analysis is critical: whereas only 1 of the 7 openness measures positively affects growth when cross-section data are employed, 3 of the 7 proxies for openness reveal a positive association with growth when the data are averaged over five-year periods, and 6 of the 7 measures are statistically significant (in either levels or differences) using annual data.

Nevertheless, the results could be perceived are surprisingly robust: when openness is statistically significant in any of the many specifications explored in this paper, we find that greater openness is associated with higher growth. Although sensitivity tests reveal the fragility of many of these results, half of the measures presented in the paper do exhibit a robust relationship with GDP growth. 
Two issues have been highlighted by this paper as critical for future research. First, existing literature is still unresolved on the issue of causality. The results of the vector autoregressions reported in this paper suggest that the causality between openness and growth runs in both directions. Although more open trade policies do precede higher growth rates, it is also true that higher growth rates lead to more open trade regimes.

Second, the different results which arise from the use of cross-section and panel data suggest the importance of disentangling short-run from long run effects without throwing away the information in annual data. Quah and Rauch (1990) have made a first attempt to disentangle the impact of cyclical from long-run effects of policies on growth in time series data. Unfortunately, Quah and Rauch use trade shares as their proxy for openness, which is one of the least robust measure of openness in our analysis. Extending Quah and Rauch (1990) to analyze other openness measures would be a useful exercise. 


\section{Bibliography}

Ahmad. Sultan. 1994. "Improving Inter-Spatial and Inter-Temporal Comparability of National Accounts". Journal of Development Economics, (June).

Balassa. Bela. 1985. "Exports, Policy Choices, and Economic Growth in Developing Countries after the 1973 Oil Shock". Journal of Development Economics 18:23-35.

Barro, R. 1991. "Economic Growth in a Cross Section of Countries." Quarterly Journal of Economics, (May) 106.

Barro, R. and Jong-Wha Lee. 1993. "International Comparisons of Educational Attainment." Journal of Monetary Economics, 32:363-394.

Behrman, Jere and Mark Rosenzweig. 1994. "The Quality of Aggregate Inter-Country. Time-Series Data on Educational Investments and Stocks, Economically Active Populations, and Employment". Journal of Development Economics, (June).

Benhabib, J. and Mark Spiegel. 1992. "The Role of Human Capital in Economic Development: Evidence from Aggregate CrossCountry and Regional U.S. Data". Forthcoming, Journal of Monetary Economics.

Bhagwati, Jagdish. 1978. Foreign Trade Regimes and Economic Development: Anatomy and Consequences of Exchange Control Regimes. Ballinger Press for the National Bureau of Economic Research, Cambridge, Massachusetts.

Bhalla, S., and Lawrence J. Lau. 1992. "Openness, Technological Progress, and Economic Growth in Developing Countries."

Dollar, D. 1991. "Outward-oriented Developing Economies Really Do Grow More Rapidly, Evidence from 95 LDCs, 1976-85." Economic Development and Cultural Change.

Easterly, W., M. Kremer, L. Pritchett, and L. H. Summers. 1993. "Good Policy or Good Luck? Country Growth Performance and Temporary Shocks", Journal of Monetary Economics 32, pp.459-483. 
Edwards, S. 1992. "Trade Orientation, Distortions, and Growth in Developing countries," Journal of Development Economics. 39:31-57.

Esfahani, Hadi S. 1991. "Exports, Imports, and Economic Growth in Semi-Industrialized Countries." Journal of Development Economics. 35:93-116.

Geroski, P.A. 1989. "Entry, Innovation, and Productivity Growth". The Review of Economics and Statistics, 572-578.

Grossman, Gene M. and Elhanan Helpman. 1992. Innovation and Growth: Technological Competition in the Global Economy. MIT Press, Boston, Massachusetts.

Harrison. Ann E. 1994. "Productivity, Imperfect Competition, and Trade Reform: Theory and Evidence." Journal of International Economics. 36:53-73.

Heitger, Bernhard. 1986. "Import Protection and Export Performance: Their impact on Economic Growth." Weltwirtschaftliches Archiv. 260(July):1-19.

Helliwell, John F. and Alan Chung. 1991. "Macroeconomic Convergence: International Transmission of Growth and Technical Progress."

Heston, Alan. 1994. "A Brief Review of Some Problems in Using National Accounts Data in Level Comparisons and Growth Studies." Journal of Development Economics, (June).

Holtz-Eakin, Douglas, Whitney Newey and Harvey Rosen. 1988. "Estimating Vector Autogregressions with Panel Data. Econometrica. 56(6): 1371-1395.

Hsiao, M.W. 1987. Tests of casuality and exogeneity between exports and economic growth: the case of the Asian NICs, Journal of Economic Development, 12(2):143-159.

Jung, W. and P. Marshall. 1985. "Exports, Growth and Casuality in Developing Countries." Journal of Development Economics. $14: 241-250$. 
Kautman. Daniel. 1991. "Determinants of the Productivity of Projects in Developing Countries: Evidence from 1,200 Projects".

Background paper for World Development Report 1991.

Krueger, Anne O. 1978. Foreign Trade Regimes and Economic Development: Liberalization Attempts and Consequences, Cambridge, MA: Ballinger.

Krueger, Anne O. and Baran Tuncer. "An Empirical Test of the Infant Industry Argument." The American Economic Review, 72(5): 1142-1152.

Kunst, Robert M. and Dalia Marin. 1989. "On Exports and Productivity: A Causal Analysis." The Review of Economics and Statistics. 699-703.

Leamer, $\quad$ Edward E. 1988. "Measures of Openness," in Robert E. Baldwin.editor, Trade Policy Issues and Empirical Analysis.

Levin. Andrew and Lakshmi K. Raut. 1992. "Complementarities Between Exports and Human Capital in Economic Growth: Evidence from the Semi-Industrialized Countries." University of California, San Diego Discussion Paper 92-14 (April).

Levine, $\quad$ Ross and David Renelt. 1992. "A Sensitivity Analysis of CrossCountry Growth Regressions." American Economic Review, 82(4):942-963.

Lichtenberg, Frank. 1994. "Testing the Convergence Hypothesis." The Review of Economics and Statistics. 576-579.

Lopez, $\quad$ Ramon. 1990. "Economic Growth, Capital Accumulation and Trade Policy in LDCs". (July) Trade Policy Division, Country Economics Department, World Bank, Washington, D.C.

Nehru, $\quad$ V. and A. Dhareshwar. 1993. "A New Database on Physical Capital Stock: Sources, Methodology, and Results." Revista de Analisis Economico, (June) Vol 8, No 1, 37-59.

Nehru, $\quad$ V., E. Swanson, and A. Dubey. 1993. "A New Database on Human Capital Stock: Sources, Methodology, and Results," Forthcoming, Journal of Development Economics. 
Nickell, S. 1981. "Biases in Dynamic Models with Fixed Effects", Econometrica, 49, 1417-1426.

Nishimizu, Mieko and John M. Page, Jr. 1990. "Trade Policy, Market Orientation, and Productivity Change in Industry", in J. de Melo and A. Sapir, eds. , Trade Theory and Economic Reform North. South, and East.

Nishimizu, M. and Sherman Robinson. 1984. "Trade Policies and Productivity Change in Semi-Industrialized Countries." Journal of Development Economics, 16:177-206.

Pack, H. 1988. "Industrialization and Trade", Chapter 9 in Handbook of Development Economics, Volume I, edited by H. Chenery and T.N. Srinivasan, Elsevier Science Publishers, B.V.

Papageorgiou D., M. Michaely and A. Choksi, 1991, eds., Liberalizing Foreign Trade: Lessons of Experience in the Developing World. 7:1-440. Basil Blackwell, Cambridge, Massachusetts.

Perkins, Dwight H. and Moshe Syrquin. 1989. "Large Countries: The Influence of Size." Handbook of Development Economics, volume II. Edited by H. Chenery and T.N. Srinivasan. Elsevier Science Publishers.

Pritchett, Lant. 1991. "Measuring Outward Orientation in Developing Countries: Can it be done?". PRE Working Paper 566. World Bank.

Quah, Danny and James E. Rauch. 1990. "Openness and the Rate of Economic Growth." Preliminary draft (October). Economics Department, Massachusetts Institute of Technology and Economics Department, University of California San Diego, U.S.A.

Ram, R. 1985. "Exports and Economic Growth: Some Additional Evidence." Economic Development and Cultural Change, $33(2): 415-425$.

Mankiw, N. G. D. Romer and D. Weil. 1992. "A Contribution to the Empirics of Economic Growth", Quarterly Journal of Economics, (May) 407-437. 
Schiff. M. and A. Valdes. 1992. The Political Economy of Agricultural Pricing Policy: Volume 4, A Synthesis of the Economics in Developing Countries, The Johns Hopkins University Press, Baltimore. Maryland.

Solow. R.M. 1957. "Technical change and the aggregate production function". Review of Economics and Statistics 39. 312-320.

Srinivasan, T.N. 1994. "Database for Development Analysis: An Overview". Journal of Development Economics, (June).

Summers. Robert and Alan Heston. 1988. "A New Set of International Comparisons of Real Product and Price Levels: Estimates for 130 Countries, 1950-1985." Review of Income and Wealth, March: 1-24.

Syrquin. Moshe and Holl is Chenery. 1989. "Three Decades of Industrialization". The World Bank Economic Review 3(2):145181 .

Thomas, Vinod, Nadav Halevi, and Julie Stanton. 1991. "Does Policy Reform Improve Performance?n. Background paper for World Development Report 1991.

Thomas. V. and J. Nash. 1992. Best Practices: Lessons in Trade Policy Reform. New York, Oxford University Press.

Tybout, J. 1992. "Researching the Trade/Productivity Link: New Directions." The World Bank Economic Review, vol. 6, no. 2.

World Bank 1991. World Development Report 1991. New York: Oxford University Press. 
Table 1 summary evidence on openness and growth

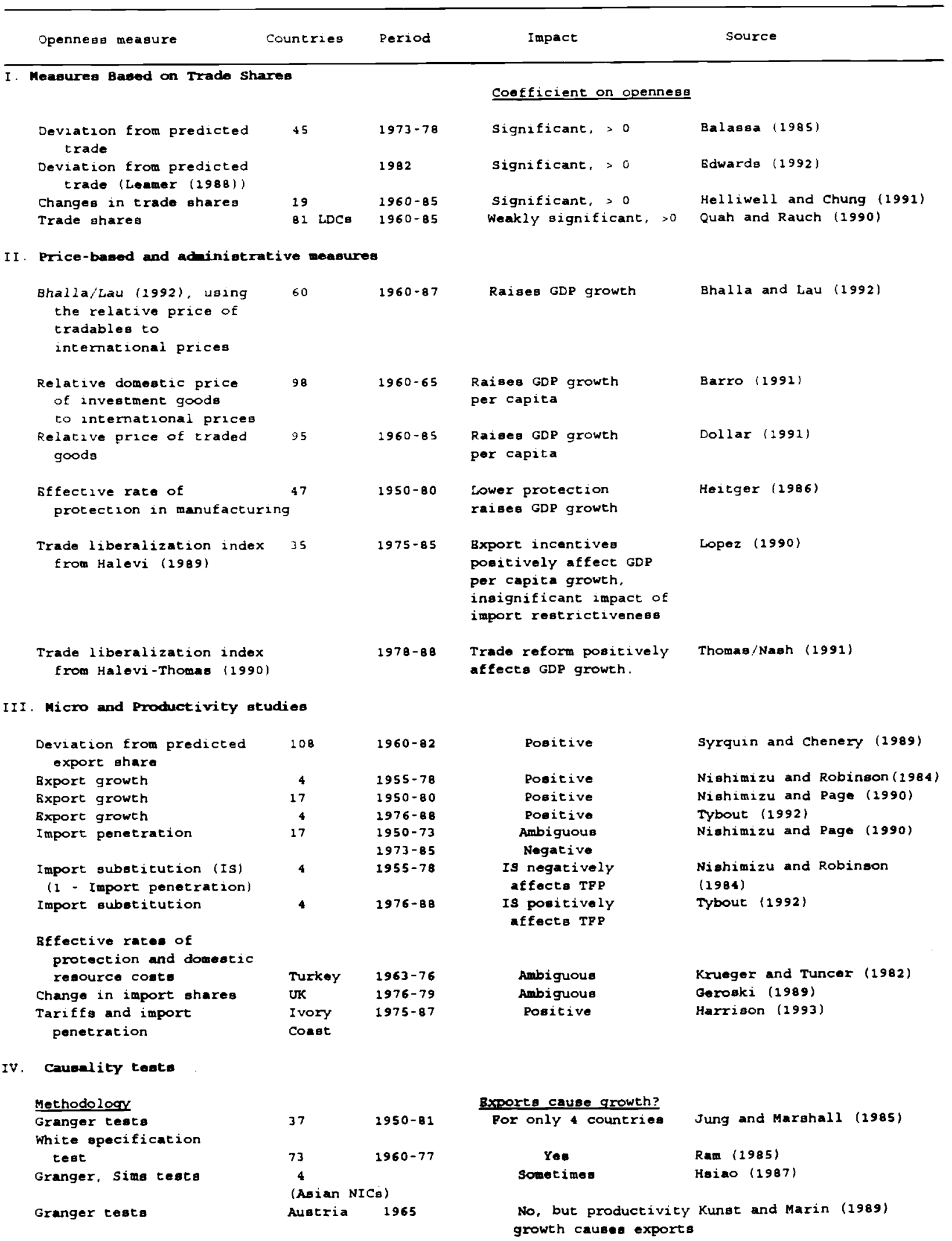




\begin{tabular}{|c|c|c|c|c|c|c|}
\hline & TR I & TR II & BLACK & DOLLAR & $\begin{array}{l}\text { TRADE } \\
\text { SHARES }\end{array}$ & INDIRECT \\
\hline Trade reform (TR I) & 1.0 & .20 & $44 * *$ & .36 & $.70 * * *$ & .37 \\
\hline$(2960-84)$ & 1.0 & $.73 * 1 *$ & $-.37 * * *$ & .08 & $.51 * *$ & $.38 * * *$ \\
\hline Trade reform & & 1.0 & $-.39 * * *$ & .05 & .06 & .20 \\
\hline$(1979-88) \quad(\mathrm{TR}$ II $)$ & & 1.0 & $-.34 * * *$ & $-.14 * *$ & $.26 * *$ & $.52 \cdots$ \\
\hline Black market premium (BLACK) & & & $\begin{array}{l}1.0 \\
1.0\end{array}$ & $\begin{array}{r}-.07 \\
.00\end{array}$ & $\begin{array}{l}-.16 \\
-.21 * * *\end{array}$ & $\begin{array}{l}-.61 * * t \\
-.47 * *\end{array}$ \\
\hline Price distortion (DOLLAR) & & & & $\begin{array}{l}1.0 \\
1.0\end{array}$ & $\begin{array}{l}.11 \\
.06 *\end{array}$ & $\begin{array}{l}.50 * " \\
.22 * " *\end{array}$ \\
\hline Trade shares & & & & & $\begin{array}{l}1.0 \\
1.0\end{array}$ & $\begin{array}{l}.25 \\
.36 * \pi\end{array}$ \\
\hline $\begin{array}{l}\text { Digprotection of } \\
\text { agriculture (INDIRECT) }\end{array}$ & & & & & & $\begin{array}{l}1.0 \\
1.0\end{array}$ \\
\hline
\end{tabular}

Table 3 Spearman Rank Corralations for Changes in Openness 1

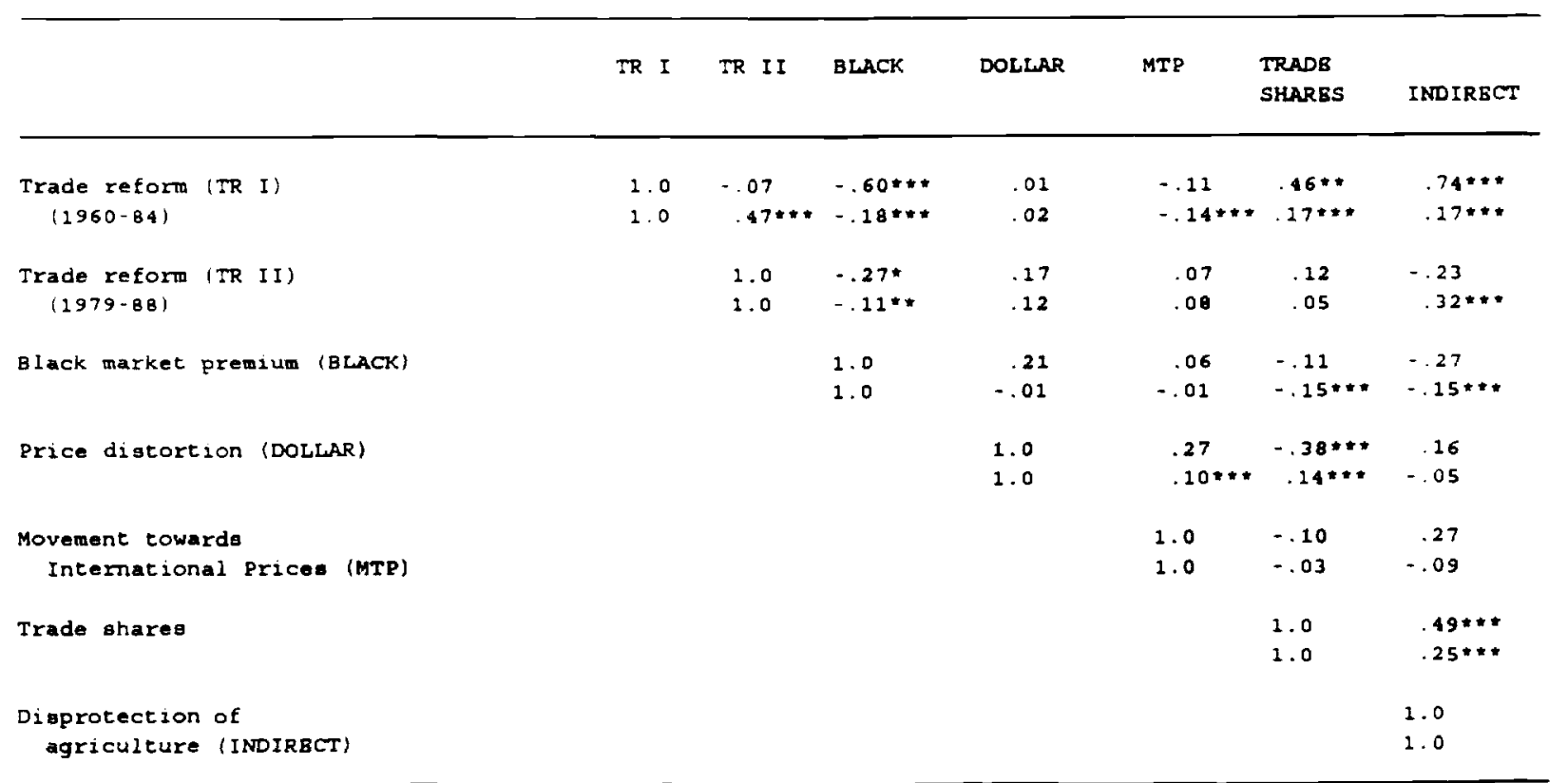

Notes: $1 /$ Top figure indicateg rank correlation for coefficients averaged over antire time period; bottom figure gives annual date rank correlations.

- Indicates significant at 15 level; * indicates oignificant at 10 level; t* indicater oignificant at 5

t Level. 
Table 4: Cross-section estimation using twenty-seven year averages and levels of trade policy.

\begin{tabular}{|c|c|c|c|c|c|c|}
\hline & (1) & (2) & (3) & (4) & $(5)$ & (6) \\
\hline Constant & $\begin{array}{l}0.01 \\
(.01)\end{array}$ & $\begin{array}{l}0.00 \\
(.01)\end{array}$ & $\begin{array}{l}0.02^{*} \\
(.01)\end{array}$ & $\begin{array}{l}0.00 \\
1.01\end{array}$ & $\begin{array}{l}0.01 \\
(.01)\end{array}$ & $\begin{array}{l}0.00 \\
(.02)\end{array}$ \\
\hline GDP in 1960 & $\begin{array}{l}0.00 \\
(.00) \\
\end{array}$ & $\begin{array}{l}0.00 \\
(.00) \\
\end{array}$ & $\begin{array}{l}0.00 \\
(.00) \\
\end{array}$ & $\begin{array}{l}0.00 \\
(.00) \\
\end{array}$ & $\begin{array}{l}0.00 \\
(.00) \\
\end{array}$ & $\begin{array}{r}0.00 \\
(.00) \\
\end{array}$ \\
\hline $\begin{array}{l}\text { Choksi et al } \\
\text { Index (TR I) }\end{array}$ & $\begin{array}{l}0.04 \\
(.11)\end{array}$ & - & -- & -- & -- & - \\
\hline Halevi Index (TR II) & -- & $\begin{array}{l}0.00 \\
(.00)\end{array}$ & - & -- & -- & - \\
\hline $\begin{array}{l}\text { Black Market } \\
\text { Premium (Black) }\end{array}$ & - & - & $\begin{array}{c}-0.02^{*} \\
(.01) \\
\end{array}$ & -- & - & - \\
\hline $\begin{array}{l}\text { Dollar Index } \\
\text { (Dollar) }\end{array}$ & -- & -- & -- & $\begin{array}{l}0.01 \\
(.02) \\
\end{array}$ & -- & - \\
\hline $\begin{array}{l}\text { Trade Share } \\
\text { (TR SHARE) }\end{array}$ & -- & -- & -- & -- & $\begin{array}{l}0.00 \\
(.01) \\
\end{array}$ & - \\
\hline $\begin{array}{l}\text { Kreuger et al. } \\
\text { (Indirect) }\end{array}$ & -- & -- & -- & - & - & $\begin{array}{r}0.53 \\
(2.04) \\
\end{array}$ \\
\hline Land & $\begin{array}{l}0.04 \\
(.27) \\
\end{array}$ & $\begin{array}{l}0.17 \\
(.31) \\
\end{array}$ & $\begin{array}{r}-0.12 \\
(.18) \\
\end{array}$ & $\begin{array}{l}0.10 \\
(.18) \\
\end{array}$ & $\begin{array}{l}-0.16 \\
(.21) \\
\end{array}$ & $\begin{array}{l}-0.16 \\
(.26) \\
\end{array}$ \\
\hline Labor Force & $\begin{array}{l}0.16 \\
(.29) \\
\end{array}$ & $\begin{array}{l}0.89^{\circ} \\
(.39)\end{array}$ & $\begin{array}{l}0.50^{*} \\
(.22) \\
\end{array}$ & $\begin{array}{l}0.34 \\
(.31) \\
\end{array}$ & $\begin{array}{l}0.41 \\
(.24) \\
\end{array}$ & $\begin{array}{l}0.34 \\
(.42) \\
\end{array}$ \\
\hline $\begin{array}{l}\text { Stock of Primary } \\
\text { Education (Primstock) }\end{array}$ & $\begin{array}{l}0.39 \\
(.24) \\
\end{array}$ & $\begin{array}{l}-0.03 \\
(.11) \\
\end{array}$ & $\begin{array}{l}0.04 \\
(.08) \\
\end{array}$ & $\begin{array}{l}0.06 \\
(.15) \\
\end{array}$ & $\begin{array}{l}0.05 \\
(.09) \\
\end{array}$ & $\begin{array}{l}0.13 \\
(.23) \\
\end{array}$ \\
\hline $\begin{array}{l}\text { Stock of Secondary } \\
\text { Education (Selstock) }\end{array}$ & $\begin{array}{l}-0.04 \\
(.09) \\
\end{array}$ & $\begin{array}{l}-0.10 \\
(.06) \\
\end{array}$ & $\begin{array}{r}-0.10^{*} \\
(.05) \\
\end{array}$ & $\begin{array}{l}-0.07 \\
(.07) \\
\end{array}$ & $\begin{array}{l}-0.09 \\
(.05) \\
\end{array}$ & $\begin{array}{l}-0.10 \\
(.13) \\
\end{array}$ \\
\hline KStock & $\begin{array}{l}0.41^{*} \\
(.12)\end{array}$ & $\begin{array}{l}.51^{*} \\
(.09) \\
\end{array}$ & $\begin{array}{l}0.46^{*} \\
(.07) \\
\end{array}$ & $\begin{array}{l}0.59^{*} \\
(.08)\end{array}$ & $\begin{array}{l}.53^{*} \\
(.08) \\
\end{array}$ & $\begin{array}{l}0.63^{*} \\
(.09) \\
\end{array}$ \\
\hline $\mathrm{N}$ & 16 & 28 & 51 & 28 & 51 & 17 \\
\hline$R$-square & .91 & .76 & .69 & .84 & .64 & .91 \\
\hline
\end{tabular}

Note: Standard errors in ( ). $\mathrm{A}^{\text {"*" }}$ indicates statistical significance at the 5\% level. 
Table 5: Fixed Effect Estimation using annual data and levels of trade policy

\begin{tabular}{|c|c|c|c|c|c|c|}
\hline & (1) & (2) & (3) & (4) & (5) & (6) \\
\hline TR I & $\begin{array}{l}0.015 \\
(.059)\end{array}$ & -- & -- & -. & -. & -- \\
\hline TR II & -- & $\begin{array}{l}0.019^{*} \\
(.005)\end{array}$ & - & - & - & -- \\
\hline Black & -- & - & $\begin{array}{r}-0.016^{\circ} \\
(.004)\end{array}$ & - & - & - \\
\hline Dollar & -- & - & - & $\begin{array}{c}-0.05^{*} \\
(.02) \\
\end{array}$ & -- & - \\
\hline TR Share & -. & -- & - & -- & $\begin{array}{r}-0.01 \\
(.02) \\
\end{array}$ & - \\
\hline Indirect & -- & - & - & -. & - & $\begin{array}{c}3.20 \\
(1.75) \\
\end{array}$ \\
\hline Land & $\begin{array}{l}0.00 \\
(.03) \\
\end{array}$ & $\begin{array}{l}0.19 \\
(.21) \\
\end{array}$ & $\begin{array}{l}0.17^{*} \\
(.06)\end{array}$ & $\begin{array}{r}0.00 \\
(.03) \\
\end{array}$ & $\begin{array}{l}0.07 \\
(.04) \\
\end{array}$ & $\begin{array}{l}0.09 \\
(.08) \\
\end{array}$ \\
\hline Labor Force & $\begin{array}{l}(0.32) \\
(.31)\end{array}$ & $\begin{array}{l}-0.17 \\
(.25)\end{array}$ & $\begin{array}{l}0.35^{*} \\
(.19)\end{array}$ & $\begin{array}{c}-0.14 \\
(.18)\end{array}$ & $\begin{array}{l}0.33 \\
(.18)\end{array}$ & $\begin{array}{l}0.22 \\
(.30)\end{array}$ \\
\hline Primstock & $\begin{array}{l}0.35 \\
(.28) \\
\end{array}$ & $\begin{array}{l}-0.26 \\
(.43) \\
\end{array}$ & $\begin{array}{l}0.10 \\
(.12) \\
\end{array}$ & $\begin{array}{l}-0.02 \\
(.15) \\
\end{array}$ & $\begin{array}{l}0.09 \\
(.10)\end{array}$ & $\begin{array}{l}0.10 \\
(.16)\end{array}$ \\
\hline Secstock & $\begin{array}{l}-0.21 \\
(.13) \\
\end{array}$ & $\begin{array}{l}-0.16 \\
(.19) \\
\end{array}$ & $\begin{array}{l}0.13^{\circ} \\
(.05) \\
\end{array}$ & $\begin{array}{l}0.08 \\
(.09) \\
\end{array}$ & $\begin{array}{l}0.07^{*} \\
(.03) \\
\end{array}$ & $\begin{array}{r}0.03 \\
(.10) \\
\end{array}$ \\
\hline KStock & $\begin{array}{c}0.53^{*} \\
(.07) \\
\end{array}$ & $\begin{array}{l}0.75^{*} \\
(.14) \\
\end{array}$ & $\begin{array}{l}0.49^{*} \\
(.05) \\
\end{array}$ & $\begin{array}{l}0.54^{*} \\
(.05) \\
\end{array}$ & $\begin{array}{l}0.56^{\circ} \\
(.04) \\
\end{array}$ & $\begin{array}{l}0.46^{\circ} \\
(.07) \\
\end{array}$ \\
\hline F-Value & 0.9 & $1.6^{\circ}$ & $1.6^{*}$ & 1.2 & $1.6^{\circ}$ & 1.1 \\
\hline $\mathrm{N}$ & 357 & 237 & 1208 & 757 & 1322 & 395 \\
\hline R-Square & .28 & .35 & .25 & .28 & .22 & .33 \\
\hline
\end{tabular}

Note: Standard errors in ( ). A "*" indicates statistical significance at the $5 \%$ level. 
Table 6: Fixed Effect Estimation using Five-year Averages and Levels of Trade Policy

\begin{tabular}{|c|c|c|c|c|c|c|}
\hline & (1) & (2) & (3) & (4) & (5) & (6) \\
\hline TR I & $\begin{array}{l}0.08 \\
(.08)\end{array}$ & - & - & -- & - & - \\
\hline TR II & - & $\begin{array}{l}0.02^{*} \\
(.01) \\
\end{array}$ & -- & -- & -- & - \\
\hline Black & -- & - & $\begin{array}{c}-0.018^{*} \\
(.005)\end{array}$ & -- & - & - \\
\hline Dollar & -- & - & -- & $\begin{array}{r}-0.039 \\
(.022)\end{array}$ & - & -- \\
\hline TR Share & -- & - & -- & - & $\begin{array}{l}-0.03 \\
(.03) \\
\end{array}$ & - \\
\hline Indirect & -- & -- & -- & - & - & $\begin{array}{c}0.31 \\
(2.11)\end{array}$ \\
\hline Land & $\begin{array}{l}0.01 \\
(.12) \\
\end{array}$ & $\begin{array}{r}1.56 \\
(.91) \\
\end{array}$ & $\begin{array}{l}0.08 \\
(.10) \\
\end{array}$ & $\begin{array}{l}-0.03 \\
(.09) \\
\end{array}$ & $\begin{array}{l}0.05 \\
(.09) \\
\end{array}$ & $\begin{array}{r}-0.31 \\
(.20) \\
\end{array}$ \\
\hline Labor Force & $\begin{array}{c}(0.64) \\
(.45) \\
\end{array}$ & $\begin{array}{c}-0.78 \\
(.86) \\
\end{array}$ & $\begin{array}{l}0.06 \\
(.23) \\
\end{array}$ & $\begin{array}{l}-0.29 \\
(.29) \\
\end{array}$ & $\begin{array}{l}0.02 \\
(.24) \\
\end{array}$ & $\begin{array}{l}0.42 \\
(.40) \\
\end{array}$ \\
\hline Primstock & $\begin{array}{l}0.65 \\
(.35)\end{array}$ & $\begin{array}{l}-0.47 \\
(.59)\end{array}$ & $\begin{array}{l}0.22 \\
(.12)\end{array}$ & $\begin{array}{l}-0.02 \\
(.19)\end{array}$ & $\begin{array}{l}0.12 \\
(.13)\end{array}$ & $\begin{array}{l}0.17 \\
(.18)\end{array}$ \\
\hline Secstock & $\begin{array}{l}-0.29 \\
(.18) \\
\end{array}$ & $\begin{array}{l}-0.54 \\
(.36) \\
\end{array}$ & $\begin{array}{l}-0.03 \\
(.07) \\
\end{array}$ & $\begin{array}{l}0.10 \\
(.13) \\
\end{array}$ & $\begin{array}{l}0.01 \\
(.06) \\
\end{array}$ & $\begin{array}{l}0.05 \\
(.12) \\
\end{array}$ \\
\hline KStock & $\begin{array}{l}0.49^{*} \\
(.09) \\
\end{array}$ & $\begin{array}{l}1.04^{*} \\
(.24)\end{array}$ & $\begin{array}{l}0.45^{\circ} \\
(.05)\end{array}$ & $\begin{array}{l}0.51^{*} \\
(.07)\end{array}$ & $\begin{array}{l}0.52^{*} \\
(.05) \\
\end{array}$ & $\begin{array}{l}0.37^{*} \\
(.08) \\
\end{array}$ \\
\hline F-Value & 0.9 & 1.1 & $1.7^{*}$ & 1.0 & $1.5^{\circ}$ & 1.3 \\
\hline$N$ & 78 & 50 & 234 & 141 & 251 & 84 \\
\hline R-Square & .61 & .87 & .64 & .63 & .59 & 69 \\
\hline
\end{tabular}

Note: Standard errors in ( ). A "*" indicates statistical significance at the $5 \%$ level. 
Table 7: The Impact of Changes in Trade Policy on GDP Growth

\begin{tabular}{||l|c|c|c|}
\hline & Annual Data & Five Year Averages & Period Averages \\
\hline TR I & $0.21^{*}$ & $0.43^{*}$ & 0.95 \\
& $(.10)$ & $(.19)$ & $(.75)$ \\
\hline TR II & 0.01 & 0.02 & $-0.04^{*}$ \\
& $(.01)$ & $(.05)$ & $(.02)$ \\
\hline Black & $-0.011^{*}$ & $-0.03^{*}$ & $-0.16^{*}$ \\
& $(.004)$ & $(.01)$ & $(.08)$ \\
\hline Dollar & 0.03 & 0.09 & -0.46 \\
& $(.04)$ & $(.12)$ & $(.26)$ \\
\hline TR Share & $0.08^{*}$ & 0.06 & 0.45 \\
& $(.04)$ & $(.08)$ & $(.45)$ \\
\hline Indirect & -0.88 & 10.07 & 11.20 \\
& $(2.41)$ & 7.81 & $(33.33)$ \\
\hline Movement Towards & $0.05^{*}$ & 0.02 & -0.00 \\
International Prices & $(.01)$ & $(.04)$ & $(.08)$ \\
(MTIP) & & & 0 \\
\hline
\end{tabular}

Note: Standard errors in ( ). A "*" indicates statistical significance at the $5 \%$ level. 
Table 8 Openness and growth: synthesis of findings

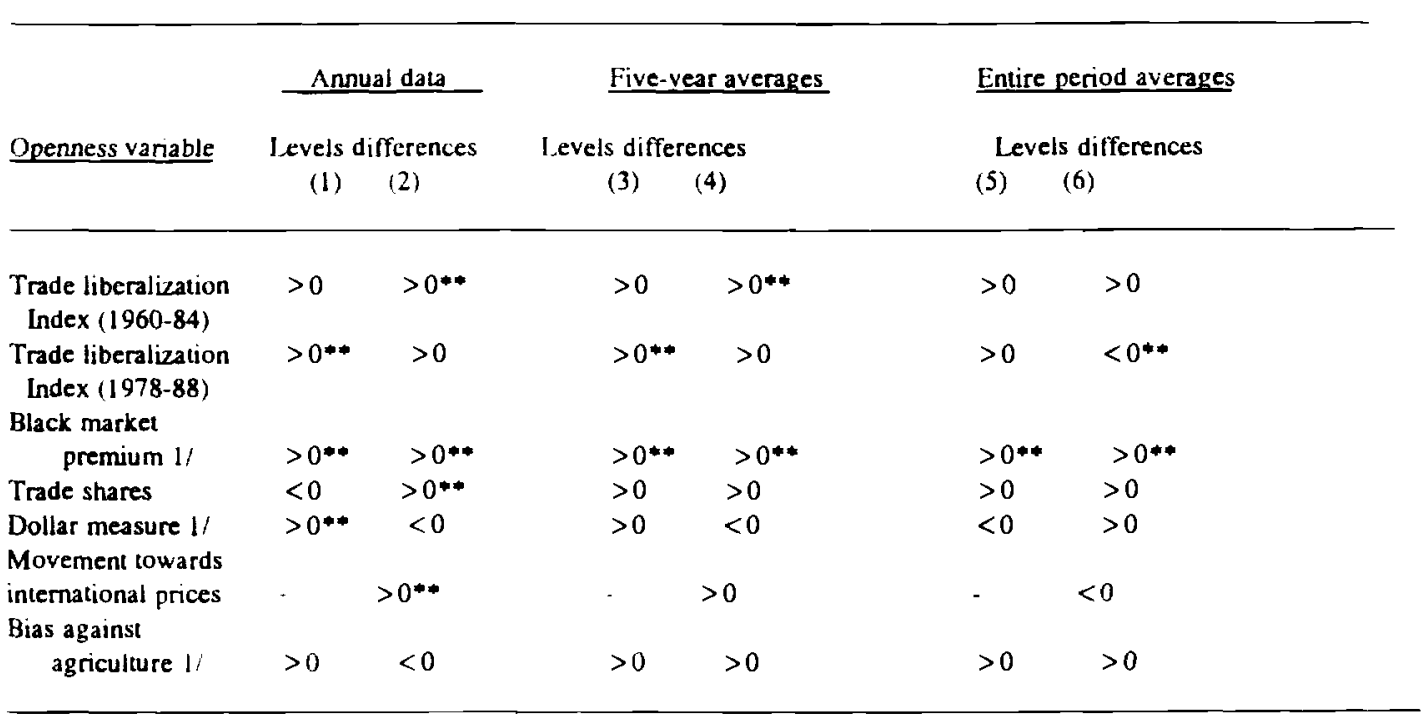

* Indicates significant at 5 percent levei.

Notes: All regressions except entire period average include country dummies. For purposes of comparison, a value of " $>0^{n}$ indicates that more openness (less distortion) positively affects growth. Consequently, for the black market premium. price distortion measures. and bias against agriculture, this table will show " $>0$ " when a higher level of distortion negatively affects growth. 
Table 9: Testing for the Interaction Between Openness and the Level of Educational Stock

\begin{tabular}{|c|c|c|c|c|}
\hline & \multicolumn{2}{|c|}{ Annual Data } & \multicolumn{2}{|c|}{ Five Year Averages } \\
\hline & $\begin{array}{l}\text { Level of Trade } \\
\text { Policy }\end{array}$ & $\begin{array}{c}\text { Changes in Trade } \\
\text { Policy }\end{array}$ & $\begin{array}{c}\text { Level of Trade } \\
\text { Policy }\end{array}$ & $\begin{array}{r}\text { Changes in } \\
\text { Polic } \\
\end{array}$ \\
\hline $\begin{array}{l}\text { TRI* Primstock } \\
\text { TRI* Secstock }\end{array}$ & $\begin{array}{l}-0.13^{*} \\
(.05) \\
-0.05 \\
(.15)\end{array}$ & $\begin{array}{l}0.34 \\
(.27) \\
-0.18 \\
(.13) \\
\end{array}$ & $\begin{array}{l}-0.13^{*} \\
(.06) \\
0.07 \\
(.17) \\
\end{array}$ & $\begin{array}{l}-0.1 \\
(.16 \\
-0.3 i \\
(.85 \\
\end{array}$ \\
\hline $\begin{array}{l}\text { TR II* Primstock } \\
\text { TR II * Secstock }\end{array}$ & $\begin{array}{l}0.00 \\
(.00) \\
0.01 \\
(.01)\end{array}$ & $\begin{array}{l}0.00 \\
(.01) \\
0.02 \\
(.02)\end{array}$ & $\begin{array}{l}0.00 \\
(.01) \\
0.00 \\
(.02) \\
\end{array}$ & $\begin{array}{l}0.01 \\
(.04) \\
0.04 \\
(.19)\end{array}$ \\
\hline $\begin{array}{l}\text { Black* Primstock } \\
\text { Black* Secstock }\end{array}$ & $\begin{array}{l}-0.02^{*} \\
(.01) \\
0.01 \\
(.02) \\
\end{array}$ & $\begin{array}{l}0.00 \\
(.00) \\
0.00 \\
(.02) \\
\end{array}$ & $\begin{array}{c}-0.009^{\circ} \\
(.004) \\
0.03 \\
0.02 \\
\end{array}$ & $\begin{array}{l}0.00 \\
(.01) \\
0.04 \\
(.08)\end{array}$ \\
\hline $\begin{array}{l}\text { Dollar * Primstock } \\
\text { Dollar * Secstock }\end{array}$ & $\begin{array}{l}0.01 \\
(.01) \\
0.05 \\
(.06)\end{array}$ & $\begin{array}{l}0.03 \\
(.02) \\
-0.03 \\
(.16)\end{array}$ & $\begin{array}{l}0.01 \\
(.01) \\
0.07 \\
(.08)\end{array}$ & $\begin{array}{l}0.00 \\
(.07) \\
-0.23 \\
(.53)\end{array}$ \\
\hline $\begin{array}{l}\text { TR Share * Primstock } \\
\text { TR Share * Secstock }\end{array}$ & $\begin{array}{l}-0.03^{*} \\
(.01) \\
0.07^{*} \\
(.03) \\
\end{array}$ & $\begin{array}{l}-0.04 \\
(.04) \\
0.03 \\
(.15) \\
\end{array}$ & $\begin{array}{l}-0.03 \\
(.02) \\
0.09^{*} \\
(.04) \\
\end{array}$ & $\begin{array}{l}-0.10 \\
(.12) \\
0.50 \\
(.44) \\
\end{array}$ \\
\hline $\begin{array}{l}\text { MTIP * Primstock } \\
\text { MTIP * Secstock }\end{array}$ & $\begin{array}{l}-- \\
--\end{array}$ & $\begin{array}{l}0.00 \\
(.01 \\
0.08 \\
(.06)\end{array}$ & -- & $\begin{array}{l}(.06) \\
0.05 \\
(.04) \\
0.50 \\
(.20)\end{array}$ \\
\hline
\end{tabular}

Note: Standard errors in ( ). A "*" indicates statistical significance at the $5 \%$ level. 
Table 10: Sensitivity Results for Openness Variables (Dependent Variable: Growth Rate of Real GDP)

\begin{tabular}{|c|c|c|c|c|c|}
\hline \multicolumn{2}{|c|}{ Openness Variable } & $\begin{array}{l}\text { Government } \\
\text { Consumption }\end{array}$ & Inflation & $\begin{array}{l}\text { Terms of } \\
\text { Trade }\end{array}$ & $N(o b s)$ \\
\hline \multicolumn{6}{|c|}{$\underline{\text { Cross-Section Estimation }}$} \\
\hline Black & $\begin{array}{l}-0.002^{*} \\
(.01)\end{array}$ & $\begin{array}{l}0.05 \\
(.03)\end{array}$ & $\begin{array}{l}0.00 \\
(.00)\end{array}$ & $\begin{array}{l}0.00 \\
(.01)\end{array}$ & 45 \\
\hline \multicolumn{6}{|l|}{ Annual Data } \\
\hline TRI & $\begin{array}{l}0.03 \\
(.05)\end{array}$ & $\begin{array}{c}-0.05 \\
(.04)\end{array}$ & $\begin{array}{r}-0.0004^{*} \\
(.0001)\end{array}$ & $\begin{array}{l}0.003^{*} \\
(.001)\end{array}$ & 293 \\
\hline TR II 2/ & $\begin{array}{l}0.013^{\circ} \\
(.006)\end{array}$ & $\begin{array}{c}-0.27 \\
(.24)\end{array}$ & $\begin{array}{r}-0.0008^{*} \\
(.0003)\end{array}$ & $\begin{array}{l}0.00 \\
(.00)\end{array}$ & 203 \\
\hline Black 2/ & $\begin{array}{l}-0.014^{\circ} \\
(.005)\end{array}$ & $\begin{array}{r}-0.15^{*} \\
(.06)\end{array}$ & $\begin{array}{r}-0.0002^{*} \\
(.0001)\end{array}$ & $\begin{array}{l}0.00 \\
(.00)\end{array}$ & 906 \\
\hline Dollar & $\begin{array}{l}-0.021 \\
(.013)\end{array}$ & $\begin{array}{c}-0.06 \\
(.04)\end{array}$ & $\begin{array}{l}-0.0001^{*} \\
(.00005)\end{array}$ & $\begin{array}{l}0.002^{*} \\
(.001)\end{array}$ & 569 \\
\hline Tradeshare & $(.04)^{0.021 / 2 /}$ & $\begin{array}{r}-0.15^{*} \\
(.05)\end{array}$ & $\begin{array}{r}-0.0002^{\circ} \\
(.0001)\end{array}$ & $\begin{array}{l}0.00 \\
(.00)\end{array}$ & 965 \\
\hline Movement $1 /$ & $\begin{array}{l}0.05^{*} \\
(.01) \\
\end{array}$ & $\begin{array}{c}-0.04 \\
(.05)\end{array}$ & $\begin{array}{r}-0.00015^{\circ} \\
(.00005)\end{array}$ & $\begin{array}{l}0.00 \\
(.00)\end{array}$ & 481 \\
\hline \multicolumn{6}{|c|}{ Five Year Averages } \\
\hline TRI $1 /$ & $\begin{array}{l}0.28 \\
(.19)\end{array}$ & $\begin{array}{l}0.00 \\
(.03)\end{array}$ & $\begin{array}{c}-0.0002^{*} \\
(.00007)\end{array}$ & $\begin{array}{l}0.00 \\
(.00)\end{array}$ & 66 \\
\hline TR II & $\begin{array}{l}0.04^{\circ} \\
(.01)\end{array}$ & $\begin{array}{l}0.68 \\
(.46)\end{array}$ & $\begin{array}{l}0.00 \\
(.00)\end{array}$ & $\begin{array}{l}0.00 \\
(.00)\end{array}$ & 44 \\
\hline Black $2 /$ & $\begin{array}{l}0.02^{*} \\
(.01)\end{array}$ & $\begin{array}{r}-0.12^{*} \\
(.06)\end{array}$ & $\begin{array}{l}-0.003^{\circ} \\
(.0001)\end{array}$ & $\begin{array}{l}0.00 \\
(.00)\end{array}$ & 179 \\
\hline
\end{tabular}

Note: Standard errors in ( ). $\mathrm{A}^{\text {"*" }}$ indicates statistical significance at the $5 \%$ level.

1/ Openness variable in differences.

$2 /$ Includes country-specific dummy variables. 
Table 11: Relationship between openness measures and share of investment in GDP (dependent variable: share of investment in GDP)

\begin{tabular}{|c|c|c|c|c|c|c|}
\hline \multirow{3}{*}{$\begin{array}{l}\text { Openness } \\
\text { Measures }\end{array}$} & \multicolumn{2}{|c|}{ Cross-Section } & \multicolumn{2}{|c|}{ Annual Date } & \multicolumn{2}{|c|}{ Five-Year Average } \\
\hline & \multicolumn{2}{|c|}{ Openness: } & \multicolumn{2}{|c|}{ Openness: } & \multicolumn{2}{|c|}{ Openness: } \\
\hline & Levels & Differences & Levels & Differences & Levels & Differer \\
\hline TR I & $\begin{array}{c}92.64 \\
(87.97)\end{array}$ & $\begin{array}{c}550.54 \\
(908.21)\end{array}$ & $\begin{array}{l}28.17^{*} \\
(7.27)\end{array}$ & $\begin{array}{c}7.88 \\
(13.33)\end{array}$ & $\begin{array}{c}23.15 \\
(16.86)\end{array}$ & $\begin{array}{l}-13.8 \\
(47.6\end{array}$ \\
\hline TR II & $\begin{array}{c}0.62 \\
(1.22)\end{array}$ & $\begin{array}{l}-10.47 \\
(6.80)\end{array}$ & $\begin{array}{c}-0.38 \\
(.47)\end{array}$ & $\begin{array}{l}-0.35 \\
(.62)\end{array}$ & $\begin{array}{c}0.88 \\
(2.35)\end{array}$ & $\begin{array}{r}-7.2 \\
(11.5\end{array}$ \\
\hline Black & $\begin{array}{c}-4.27 \\
(3.78)\end{array}$ & $\begin{array}{c}10.89 \\
(45.73)\end{array}$ & $\begin{array}{c}-2.54^{*} \\
(.49)\end{array}$ & $\begin{array}{l}0.40 \\
(.64)\end{array}$ & $\begin{array}{c}-2.85 \\
(1.64) \\
\end{array}$ & $\begin{array}{l}10.2 \\
(3.8 \\
\end{array}$ \\
\hline Dollar & $\begin{array}{l}19.39^{*} \\
(9.01)\end{array}$ & $\begin{array}{c}115.38 \\
(149.38)\end{array}$ & $\begin{array}{c}-3.77 \\
(2.71)\end{array}$ & $\begin{array}{l}1.68 \\
(.72)\end{array}$ & $\begin{array}{l}-5.31 \\
(6.80)\end{array}$ & $\begin{array}{r}31.2 \\
(32.3 \\
\end{array}$ \\
\hline TRShare & $\begin{array}{c}31.96^{*} \\
(10.13)\end{array}$ & $\begin{array}{c}331.25 \\
(239.80)\end{array}$ & $\begin{array}{l}36.97^{*} \\
(2.95)\end{array}$ & $\begin{array}{c}4.23 \\
(4.57) \\
\end{array}$ & $\begin{array}{l}38.20^{*} \\
(7.77) \\
\end{array}$ & $\begin{array}{r}55.4 \\
(28.4 \\
\end{array}$ \\
\hline Indirect & $\begin{array}{l}2887.28^{\circ} \\
(890.38)\end{array}$ & $\begin{array}{c}8713.74^{*} \\
(10664.90)\end{array}$ & $\begin{array}{c}913.18^{*} \\
(236.58)\end{array}$ & $\begin{array}{l}-840.51^{*} \\
(325.84)\end{array}$ & $\begin{array}{l}-965.35 \\
(547.46)\end{array}$ & $\begin{array}{r}-804 . \\
(1981 .\end{array}$ \\
\hline MTIP & -- & $\begin{array}{c}-25.11 \\
(36.67)\end{array}$ & -- & $\begin{array}{c}0.64 \\
(1.62)\end{array}$ & -- & $\begin{array}{l}-3.4 \\
(8.88\end{array}$ \\
\hline
\end{tabular}

Note: Standard errors in ( ). A "*" indicates statistical significance at the $5 \%$ level. 
Table 12: Granger Causality Tests (For Annual Data Only)

\begin{tabular}{||l|c|c||}
\hline Openness Measure & $\begin{array}{c}\text { Openness }- \text { GDP }^{1 /} \\
\text { (F-Test) }\end{array}$ & $\begin{array}{c}\text { GDP } \rightarrow \text { Openness }{ }^{2 \prime} \\
\text { (F-Test) }\end{array}$ \\
\hline \hline TR I & 0.6 & 0.7 \\
\hline TR II ${ }^{4 \prime}$ & 0.9 & 0.6 \\
\hline Black $^{4 \prime}$ & $5.7^{*}$ & 2.2 \\
\hline Dollar $^{*}$ & 2.1 & 1.5 \\
\hline Trade Share $^{3 !} 4^{\prime \prime}$ & $4.3^{*}$ & $3.4^{*}$ \\
\hline Movement $^{3 /}$ & 0.5 & 1.0 \\
\hline
\end{tabular}

"Tests for the joint significance of lagged openness variables in a regression of GDP growth on lagged values of GDP growth, growth in capital stock, education. labor force. land, and openness. Lag length is three. A "*" indicates a rejection of the null hypothesis that lagged openness variables are insignificant in explaining growth at the $5 \%$ confidence level.

$2 \quad$ Tests for the joint significance of lagged GDP growth in a regression of openness on lagged values of GDP growth, growth in capital stock, education, labor force. land, and openness. A "*" indicates a rejection of the null hypothesis that lagged GDP growth is insignificant in explaining openness at the $5 \%$ confidence level.

" Openness variable in differences.

Includes country-specific dummy variables. 
Appendix 1: Country Coverage for Openness Measures

\begin{tabular}{|c|c|c|c|}
\hline TR I & TR II & Dollar & INDIRECT \\
\hline Argentina & Argentina & Argentina & Argentina \\
\hline Brazil & Bangladesh & Bangladesh & Brazil \\
\hline Chile & Brazil & Bolivia & Chile \\
\hline Colombia & Chile & Brazil & Cote d'Ivoire \\
\hline Spain & Cote d'Ivoire & Chile & Colombia \\
\hline Greece & Colombia & Colombia & Egypt \\
\hline Indonesia & Costa Rica & Costa Rica & Ghana \\
\hline Israel & Ghana & Algeria & South Korea \\
\hline South Korea & Sri Lanka & Indonesia & Egypt \\
\hline Sri Lanka & Jamaica & Guatemaia & Morocco \\
\hline Pakistan & Kenya & Haiti & Malaysia \\
\hline Philippines & South Korea & India & Pakistan \\
\hline Puerto Rico & Morocco & Indonesia & Philippines \\
\hline Singapore & Madagascar & Jamaica & Puerto Rico \\
\hline Turkey & Mexico & South Korea & Thailand \\
\hline & Mauritius & Sri Lanka & Turkey \\
\hline & Malawi & Morocco & Zambia \\
\hline & Nigeria & Mexico & \\
\hline & Pakistan & Malaysia & \\
\hline & Panama & Pakistan & \\
\hline & Philippines & Panama & \\
\hline & Senegai & Peru & \\
\hline & Thailand & Philippines & \\
\hline & Turkey & Singapore & \\
\hline & Tanzania & El Salvador & \\
\hline & Zaire & Thailand & \\
\hline & Zambia & Turkey & \\
\hline & Zimbabwe & Venezuela & \\
\hline
\end{tabular}

Black Market Premium (BLACK) and Trade Shares (TR Share)

$\begin{array}{llll}\text { Argentina } & \text { Greece } & \text { Nicaragua } & \text { Venezuela } \\ \text { Bangladesh } & \text { Guatemala } & \text { Pakistan } & \text { Zaire } \\ \text { Bolivia } & \text { Haiti } & \text { Panama } & \text { Zambia } \\ \text { Brazil } & \text { India } & \text { Peru } & \text { Zimbabwe } \\ \text { Chile } & \text { Indonesia } & \text { Philippines } & \\ \text { China } & \text { Israel } & \text { Puento Rico } & \\ \text { lvory Coast } & \text { Jamaica } & \text { Rwanda } & \\ \text { Cameroon } & \text { Kenya } & \text { Sudan } & \\ \text { Colombia } & \text { South Korea } & \text { Senegal } & \\ \text { Costa Rica } & \text { Sri Lanka } & \text { Singapore } & \\ \text { Ageria } & \text { Morocco } & \text { El Salvador } & \\ \text { Egypt } & \text { Madagascar } & \text { Thailand } & \\ \text { Spain } & \text { Mexico } & \text { Turkey } & \\ \text { Ethiopia } & \text { Mali } & \text { Tanzania } & \\ \text { Ghana } & \text { Malaysia } & \text { Uganda } & \\ & \text { Mauritius } & \text { Malawi } & \end{array}$

Movement Towards Intemational Prices (MTIP)

$\begin{array}{ll}\text { Argentina } & \text { Spain } \\ \text { Bolivia } & \text { India } \\ \text { Brazil } & \text { Indonesia } \\ \text { Chile } & \text { Jamaica } \\ \text { Cameroon } & \text { Kenya } \\ \text { Colombia } & \text { Korea } \\ \text { Costa Rica } & \text { Sri Lanka }\end{array}$

Morocco
Madagascar
Mexico
Malaysia
Pakistan
Peru
Philippines

Puerto Rico

Senegal

El Salvador

Thailand

Venezuela

Zambia

Zimbabwe 